\title{
Municipal Solid Waste Management: Circular Economy Evaluation in Turkey
}

\author{
Oylum Gökkurt Baki \\ Engineering and Architecture Faculty, Environmental Engineering Department \\ Sinop University, 57000, Sinop, Turkey \\ E-mail: ogbaki@ sinop.edu.tr (Orchid ID: 0000-0001-7823-0824) \\ Osman Nuri Ergun \\ Engineering Faculty, Environmental Engineering Department \\ Ondokuz Mayis University, Turkey \\ E-mail: onergun@ omu.edu.tr
}

Received: March 24, $2021 \quad$ Accepted: April 10, $2021 \quad$ Published: April 20, 2021

doi:10.5296/emsd.v10i2.18448ＵRL: https://doi.org/10.5296/emsd.v10i2.18448

\begin{abstract}
With the increase in environmental negativities according to wastes, priority has been given to sustainable practices and thus the circular economy $(\mathrm{CE})$, that is, the recycling of wastes to the economy, and related zero waste practices have gained priority in Turkey.

Turkey produced 32.2 million tonnes of waste overall per year and it means that waste per capita is approximately $1.16 \mathrm{~kg}$ per day and also the average recycling rate of all waste in Turkey is $12.3 \%$ according to 2018 records of TurkStat. According to these data, $20.24 \%$ of the wastes are sent to the municipal garbage disposals, $67.20 \%$ is disposed of by the regular storage method and $38 \%$ is recycled by composting. Also, according to the 2016 data, wild storage in Turkey continues at $27 \%$.

In the present study, the relationships between the yearly population growth, the increase in waste and in disposal facilities, and in the number of waste disposal facilities were examined and some relevant evaluations were made for the coming years. The projections were calculated using the data of Turkey in the coming years, the amount of waste, the amount of recycled waste, and the number of facilities. The recommendations were presented and emphasis was made for the requirements of the application of circular economy in Turkey. As
\end{abstract}


a result, the analysis results obtained showed that the increases in the amount of waste will increase both the amount of waste and the areas where the waste will be disposed of and will create serious problems in the future. A sustainable waste management system and circular economy practices require that recyclable wastes be collected separately at the source, and the recycling process is carried out in a planned structure and if possible, no waste is generated. Collecting wastes separately at the source and public participation and awareness-raising in the zero-waste process is a must for the success of this process.

Keywords: Circular economy, Waste management, Recycling, Sustainability, Waste hierarchy, Turkey

\section{Introduction}

The waste problem, due to the growing global population, consumerism and the linear approach to industrialisation, has become an increasingly severe issue in the $21^{\text {st }}$ century (Stoeva and Alriksson, 2017; D'Amato et al., 2016; Feo et al., 2019). As people's lives become more affluent, the amount of waste increases (Malinauskaite et al., 2017) and global solid waste generation is expected to triple by 2100 (World Bank, 2013). The reduction of waste contributes to the natural resource depletion, environmental pollution, for which treatment in recent years is paid so much attention (Zhang et al., 2017a; Huang et al., 2018; Liu et al., 2018, Zeng et al., 2016; Minelgaite and Liobikiené, 2019). Especially, with the technological and industrial developments in the second half of the 20th century, the damage given to the environment has increased and the decrease in non-renewable resources increased. Increasing environmental problems along with the reduction of natural resources have begun to move from the local dimension to the global dimension, problems including global warming, ozone depletion, acid rain, drought, etc. have emerged (Uslu, 1995, Demirer, 2003). Increasingly affluent lifestyles, continuing industrialization and population growth in many countries around the world has been accompanied by rapid increases in solid waste production. Municipal solid waste management is a significant problem for municipalities in terms of economical and technical aspects (Yurtseven et al., 2010; Sharloy et al., 2007). Many cities in developing countries face serious problems in managing their solid waste (Turan et al., 2016). In most of the settlement units of Turkey, the collection and transportation components of MSW management are generally well organized. The municipalities spend all of their efforts and budgets for these services. There are two types of collection systems in the municipal areas of Turkey (Ergun et al., 1998). Improper management of solid waste has serious environmental and health consequences. Such practices contribute to widespread environmental pollution as well as the spread of diseases (Gulec et al., 2001; Turan et al., 2009).

With recycling and waste minimization practices, it is possible to protect natural resources and prevent waste of resources. Also, with such applications, both the amount of waste going to the landfill will be reduced and the recyclable waste will be brought back to the economy as raw materials. Accordingly, in the Regulation on Control of Packaging Waste, which was established in 2018, a system for separate collection has been defined by accepting the separation of packaging wastes at their sources. Within this system defined in the regulation, 


\section{Macrothink}

since municipalities are responsible for the collection of wastes in the Metropolitan Municipality Law No.5216 and Municipality Law No.5393, the responsibility of collecting and transporting the packaging wastes separately at the source is given to the relevant municipalities. Municipalities prepare packaging waste management plans in accordance with the "Procedures and Principles Regarding the Preparation, Implementation, and Monitoring of Packaging Waste Management Plans" issued on 22.10.2012 to collect packaging waste separately at the source. Municipalities carry out separate collection-sorting activities at the source of packaging wastes themselves or through environment certificate-licensed/temporary operating collection-sorting facilities. Also, the relevant regulation includes the adoption of the efficient and efficient collection of household packaging wastes (glass, plastic, metal, paper-cardboard) (Turkish Environment and Urban Ministry, 2021). Licensing was initiated in 2003 for the first time to ensure that packaging waste recycling facilities operate in accordance with the regulation, to record the packaging waste collected, separated, and recycled, and to ensure the effective control of the facilities. Within the scope of license applications, the number of licensed facilities, which was 28 in 2003, increased to 831 by 2013. As of 2013, the number of municipalities in Turkey with proper waste management was determined to be 438 . This is $31.3 \%$ of the total number of municipalities in Turkey. Currently, according to the 2016 data in Turkey, the rate of wild storage was determined to be 27\% (Turkish Environment and Urban Ministry, 2021; Municipal Waste Statistics, 2016). The distribution of waste disposal and recycling facilities across Turkey in 2018 is given in Figure 1.

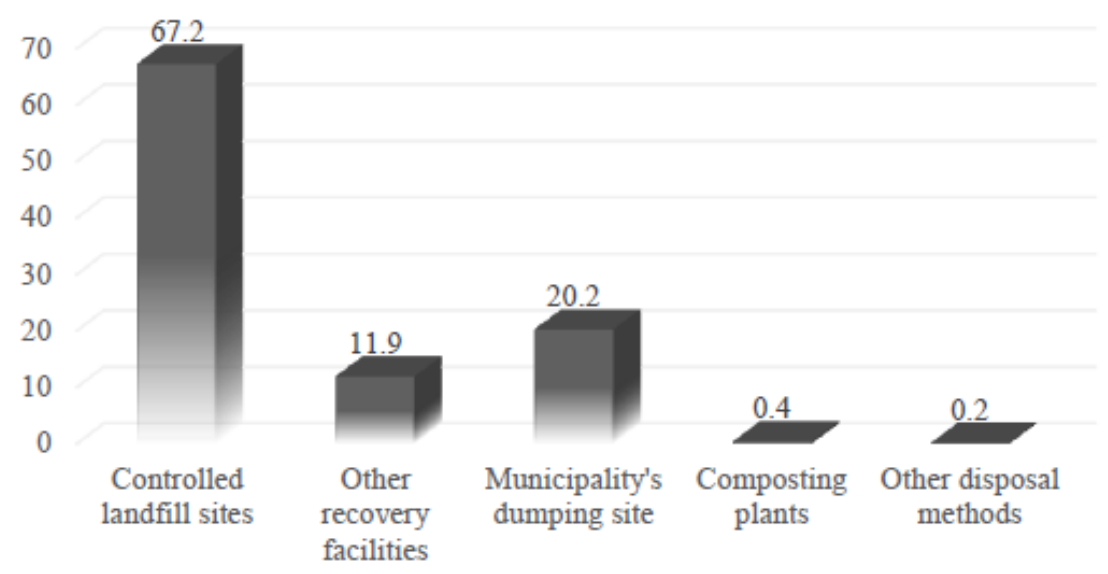

Figure 1. The percentage of waste disposal and recycling facilities in Turkey in 2018

As of 2016, the share of recycling and composting in municipal wastes was $45.3 \%$ as the average of EU-28 countries (European Commission, 2021; TurkStat, 2017). According to the National Waste Management Action Plan and this value is 13\% in Turkey as of 2016. According to 2018 records, Turkey produced 32.2 million tonnes of waste overall per year (Fig 1). It means that waste per capita is approximately $1,16 \mathrm{~kg}$ per day (Turkish Court of Accounts, 2007). Figure 2 shows the total amount of urban waste collected by disposal and recovery methods based on years. 


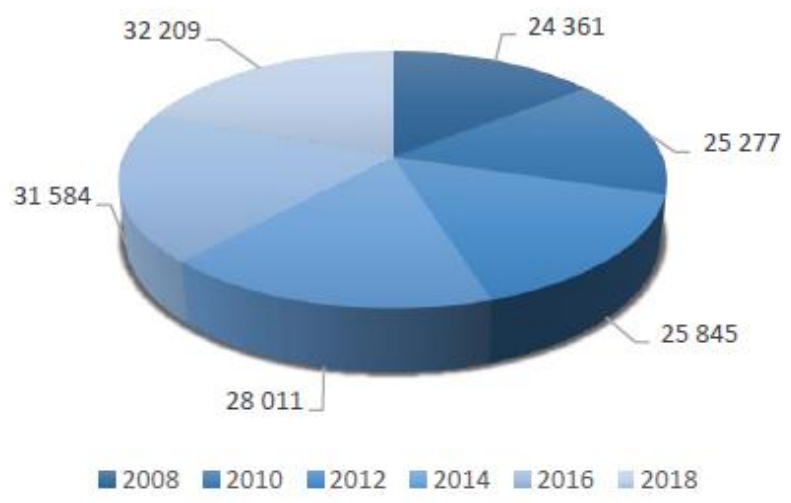

Figure 2. Total amount of collected municipal waste by disposal and recovery methods, 2008 - 2018 (TurkStat, 2020)

The average recycling rate of all waste in Turkey is $12.3 \%$. Approximately 22 million tonnes of waste go to landfills or are incinerated. The 2018 data shows that there are 2,223 waste disposal and recovery facilities in Turkey. $87.5 \%$ of waste goes to landfill facilities $(67.2 \%$ landfills and $20.3 \%$ wild dumpsites). $12.3 \%$ of it is sent to waste dumps and recycling facilities, $0.2 \%$ is burned in the open area, disposed of by burying and dumping into the stream-land. The current number of waste landfill facilities is 159 . The number of incineration plants is 40 (seven are active, the capacity is 757,000 tonnes/year, 494,000 tonnes of waste disposed in 2018) (Table 1) (Turkish Court of Accounts, 2007).

Table 1. Waste disposal and recovery facilities statistics, $2014-2018^{(1)}$ (TurkStat, 2020)

\begin{tabular}{|l|l|l|l|l|l|l|}
\hline & $\mathbf{2 0 1 4}$ & $\mathbf{2 0 1 6}$ & $\mathbf{2 0 1 8}$ \\
\hline & $\begin{array}{l}\text { Number of } \\
\text { facilities }\end{array}$ & $\begin{array}{l}\text { Amount waste } \\
\text { treated } \\
\text { (tonnes) }\end{array}$ & $\begin{array}{l}\text { Number of } \\
\text { facilities }\end{array}$ & $\begin{array}{l}\text { Amount } \\
\text { waste treated } \\
\text { (tonnes) }\end{array}$ & $\begin{array}{l}\text { Number of } \\
\text { facilities }\end{array}$ & $\begin{array}{l}\text { Amount } \\
\text { treated (tonnes) }\end{array}$ \\
\hline $\begin{array}{l}\text { Waste disposal } \\
\text { facilities }\end{array}$ & 117 & 41324637 & 140 & 44125262 & 166 & 56372769 \\
\hline $\begin{array}{l}\text { Controlled } \\
\text { landfill sites }\end{array}$ & 113 & 41281755 & 134 & 43815135 & 159 & 55878883 \\
\hline $\begin{array}{l}\text { Incineration } \\
\text { plants }\end{array}$ & 4 & 42882 & 6 & 310127 & 7 & 493885 \\
\hline $\begin{array}{l}\text { Waste recovery } \\
\text { facilities }\end{array}$ & 868 & 19724241 & 1558 & $36648986^{(\mathrm{r})}$ & 2057 & 48079834 \\
\hline $\begin{array}{l}\text { Composting } \\
\text { plants }\end{array}$ & 4 & 94019 & 7 & 140467 & 8 & 138054 \\
\hline $\begin{array}{l}\text { Co-incineration } \\
\text { plants }\end{array}$ & 39 & 532343 & 35 & 738908 & 40 & 1069360 \\
\hline $\begin{array}{l}\text { Other recovery } \\
\text { facilities }\end{array}$ & 825 & 19097879 & 1526 & $35769611^{(\mathrm{r})}$ & 2009 & 46872420 \\
\hline Total & 985 & 61048878 & 1698 & 80774248 & 2223 & 104452603 \\
\hline
\end{tabular}

TurkStat, Statistics on Environment, 2018

${ }^{(1)}$ Waste amount of facilities having licence for more than one waste disposal and recovery method are included in the related method.

${ }^{(2)}$ Includes the facilities which recover waste metal, plastic, paper, mineral, etc.

(r) Data revised. 
The ministry prepared and announced the Zero Waste Management Action Plan in 2019, which includes the strategies and actions to be implemented by 2023. The project aims to minimize waste, recycle and also reduce the volume of non-recyclable waste. The ministry has reported that 18,750 public institutions joined the project, and 126 tonnes of paper and 8,7 tonnes of glass were recycled, while 9,1 tonnes of organic waste had been composted by May 2019 (Turkish Environment and Urban Ministry, 2021a; General Directorate of Industry and Technology, 2020; Turkish Court of Accounts, 2007). Sustainable waste management and the $\mathrm{CE}$ approach includes the protection of natural resources, prevention of waste, waste reduction, and completely waste prevention-zero waste practices in Turkey. Accordingly, based on the TurkStat, the present study aimed to analyze the relationship between population growth, increase in the amount of waste, the waste of the increase in the assessed amount of waste in disposal facilities and the increase in recycling plant number and the current waste management systems in the management of the existing waste in Turkey according to yearly data. An evaluation was made about the situation of the CE approach in Turkey. Also, a description of long-term estimation was made for future years using the projection data concerning Turkey's waste. With the evaluations of all these data relationships, the current status regarding the sustainable management of wastes with economic value was evaluated and the necessity of the applications of CE in Turkey was explained.

\section{Methodology}

In this study, the relationship between the amount of solid waste and all relevant data determined and all data was obtained from Turkey Statistical Institute database (TurkStat, 2020; TurkStat, 2017). The tables and figures were prepared in Microsoft Excel 2010 software, and the relationships between solid waste amounts, recycling rates and all data related to solid waste management were analyzed by regression analysis using IBM SPSS Statistics 21 software. The fact that $R^{2}$ value is 1 in the regression analysis indicates that there is a linear relationship between the correlated data.

\subsection{Statistical Analysis of Waste Management Status}

In the statistical analyzes applied in the study, the population, total solid waste amount, the amount of waste sent to compost and other recovery facilities, the number of waste disposal facilities and the number of waste recovery facilities, and the amount of waste processed in waste recovery facilities were used as the data (Turkish Environment and Urban Ministry, 2021a). The effects of the changes in population data between 2008 and 2018 and the total amount of waste, the amount of total waste sent to compost and other recycling facilities was determined by the regression analysis. Also, the relationship between the total number of facilities for the years 2014, 2016, and 2018 (the number of waste disposal + recovery facilities), the amount of waste processed in waste recovery facilities, and the amount of waste processed in compost and other recovery facilities were determined by the regression analysis. In the study, long-term projections were calculated and evaluated between the population, total solid waste, waste sent to compost and other recovery facilities, the total number of facilities (waste disposal and recovery facilities), the amount of waste processed in the waste disposal, and recovery facilities, and waste processed in compost and other 
recovery facilities. The results obtained from all these analyzes were evaluated, and evaluations were made for the point reached and the current status in recycling practices and current waste management practices in Turkey.

The changes in the population and the total amount of waste between 2008 and 2018 were examined and the relationship was found to be positive-very high $\left(R^{2}=0,9375, p<0,01\right)$ (Fig $3 a)$. It was seen that population growth and the changes in the total amount of waste were directly proportional. Examining the relationship between the total amount of waste and the amount of waste sent to compost and other recycling facilities, it was found that there was a very high positive correlation $\left(\mathrm{R}^{2}=0,845, \mathrm{p}<0,01\right)$ (Fig $\left.3 \mathrm{~b}\right)$.
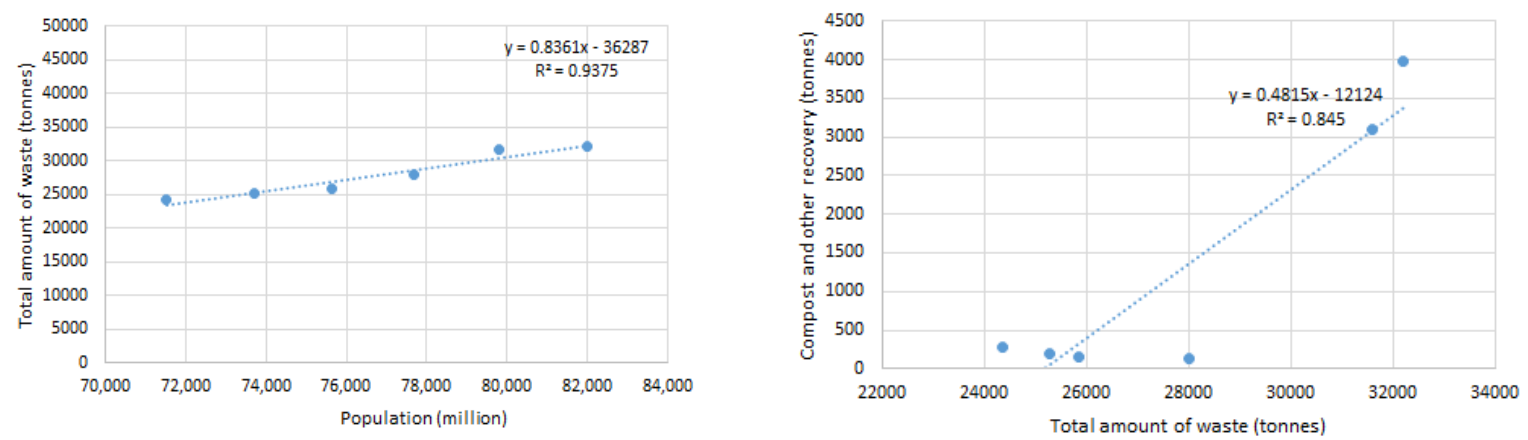

Figure 3. a)- The relationship between population and total waste amount between 2008 and 2018 b) - The relationship between total waste-compost and waste sent to other recycling facilities between 2008 and 2018
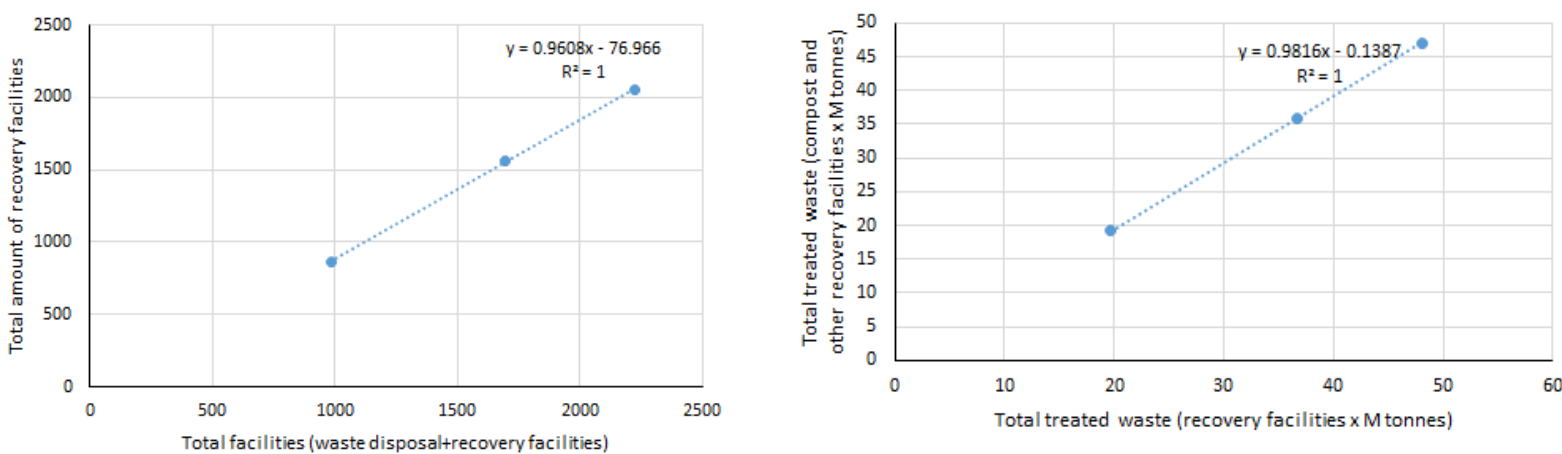

Figure 4. a)- The relation between the total number of facilities (number of waste disposal facilities + recycling facilities) and the number of all waste recovery facilities between 2014, 2016, and 2018 - b) the relationship between waste amount -compost and waste processed in other recycling facilities between 2014, 2016 and 2018

The changes between the total number of solid waste disposal facilities and the number of waste recovery facilities between 2014, 2016, and 2018 in Turkey were examined and the relationship was found to be positive-very high correlation $\left(\mathrm{R}^{2}=0,9608, \mathrm{p}<0,01\right)$ (Fig 4). It 


\section{Macrothink}

was seen that the relationship between the total number of solid waste disposal facilities and the number of waste recovery facilities was directly proportional. Examining the relationship between the amount of waste processed in waste recovery facilities and the amount of waste processed in compost and other recovery facilities, it was found that there was a very high positive relationship $\left(\mathrm{R}^{2}=1, \mathrm{p}<0,01\right)$ (Fig $\left.4 \mathrm{~b}\right)$. The results showed that the amount of waste processed in waste recovery facilities and the amount of waste processed in compost and other recovery facilities have been in a linear increase.
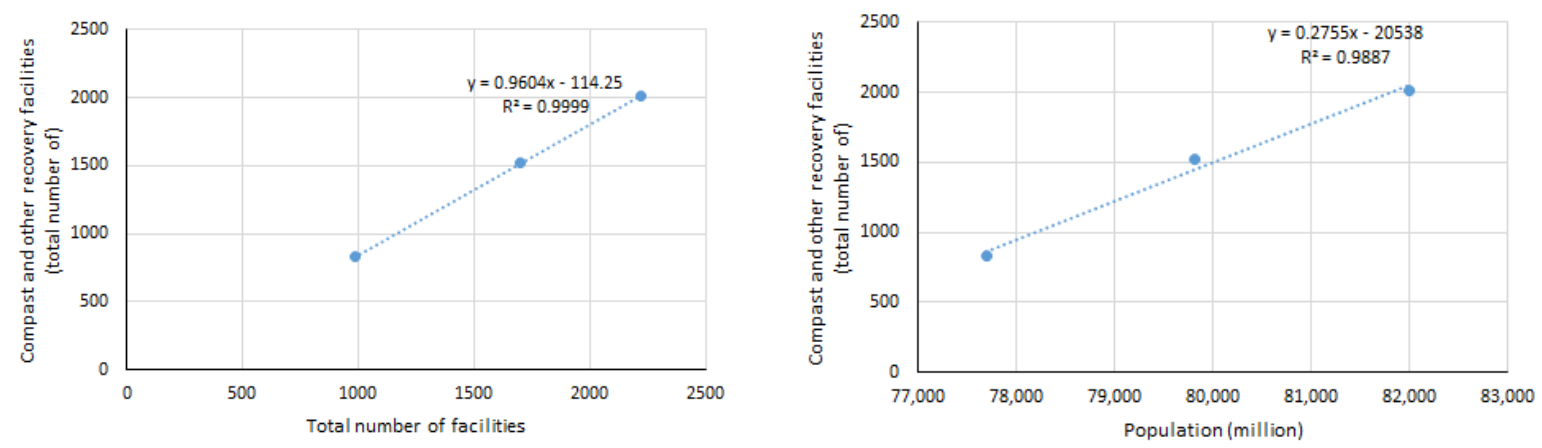

Figure 5. a) - Relationship between the total number of facilities (number of waste disposal + recovery facilities) and the number of compost and other recovery facilities between 2014, 2016, and 2018 b) - Relationship between the population and compost and other recovery facilities between 2014, 2016, and 2018

The changes between the total number of facilities and number of compost and other recovery facilities between 2014, 2016, and 2018 in Turkey were examined and the relationships were determined to be positive-very high $\left(\mathrm{R}^{2}=0,9999, \mathrm{p}<0,01\right)$ (Fig 5a). It is seen that the changes between the total number of facilities and the number of compost and other recovery facilities are directly proportional. Also, examining the relationship between the population and the number of compost and other recovery facilities, it was found that there was a very high positive correlation $\left(\mathrm{R}^{2}=0,9887, \mathrm{p}<0,01\right)$ (Fig $\left.5 b\right)$.

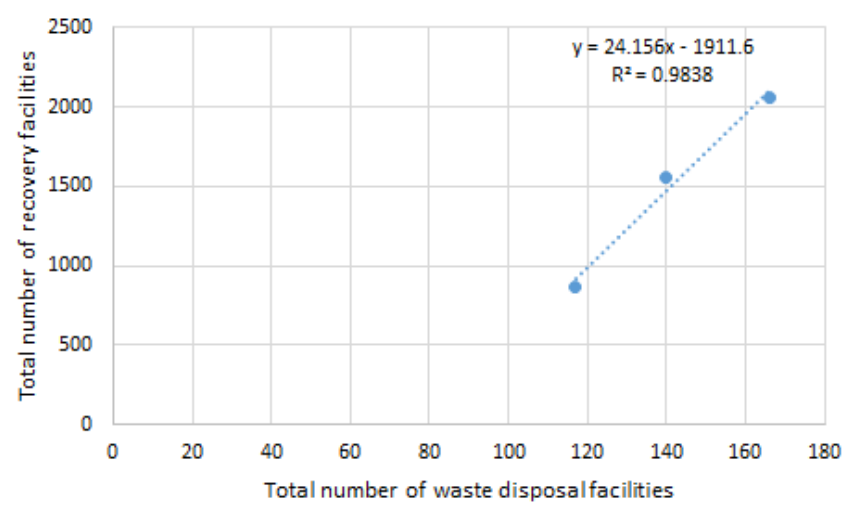

Figure 6. Relationship between the number of all waste disposal facilities and the number of all waste recovery facilities between 2014, 2016, and 2018 


\section{Macrothink}

The changes between the total number of facilities and number of compost and other recovery facilities between 2014, 2016, and 2018 in Turkey were examined and the relationships were found to be positive-very high $\left(\mathrm{R}^{2}=0,9838, \mathrm{p}<0,01\right)$ (Fig 6).

Considering Turkey's population projections, projections were established for the long-term population growth, amount of solid waste, waste disposal facilities and the number of waste recycling plant numbers, and the amount of waste sent to recycling facilities. Also, by using projection data, the long-term increase in the number of waste disposal facilities that may be needed in the future was revealed.
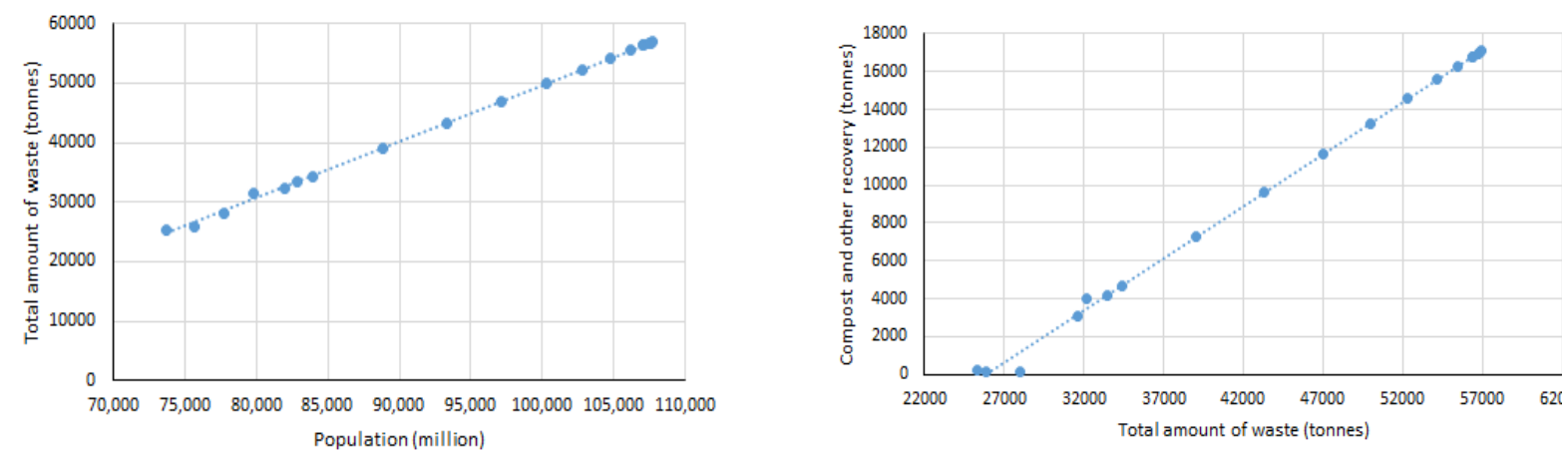

Figure 7. a) Projection between the population and the total amount of waste between the years 2008 and 2018 b) The projection between the total amount of waste-compost and waste sent to other recovery facilities between 2008 and 2018

Based on the variation between the population and the total amount of waste between 2008 and 2018, the results of the data for which long-term estimates are made are given (Fig 7a). Also, based on the variation between the total waste and the amount of waste sent to compost and other recovery facilities between 2008 and 2018, an analysis chart containing long-term estimations is given (Fig 7b). By ensuring the recycling and recovery of waste materials, the need for raw materials will also decrease. Thus, consumption, which increases in direct proportion to the population, will decrease and the consumption of natural resources will be prevented by recycling and recovering the resulting wastes, and all management stages and energy consumption with high costs will be eliminated.
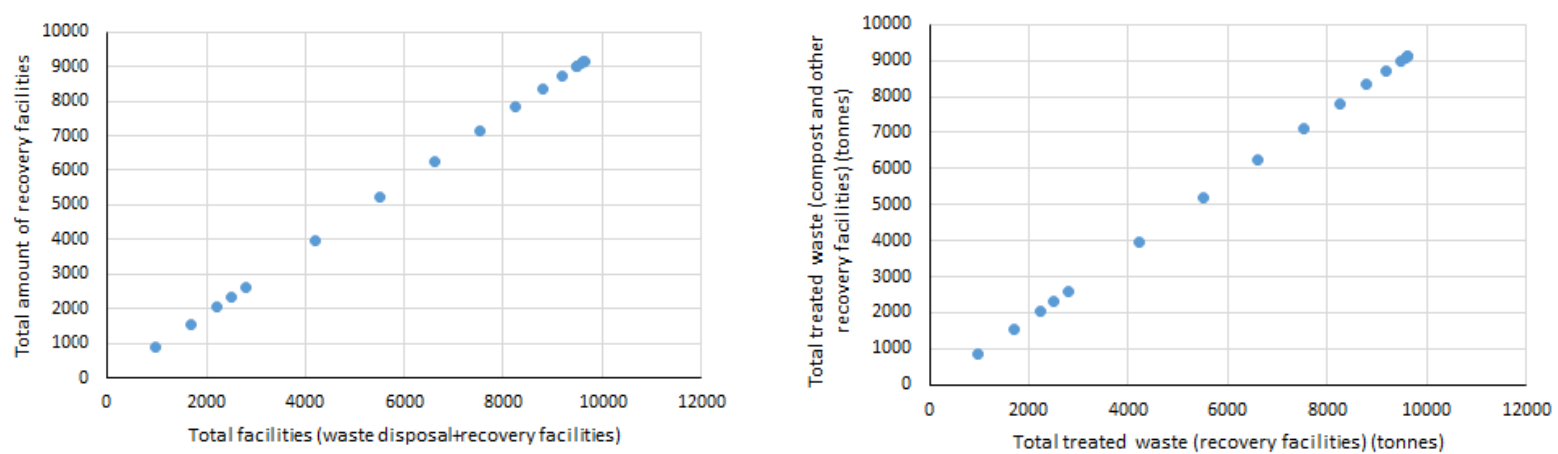

Figure 8. a) Total waste disposal facilities between 2014, 2016, and 2018 (the number of 


\section{Macrothink}

waste disposal + recovery facilities)-the projection between the numbers of all waste recovery facilities b) The amount of waste processed in all waste recovery facilities between 2014, 2016, and 2018- the projection between the amount of waste treated in compost and other recovery facilities

Another relationship examination with other data in the study was the long-term prediction graphic for the total waste disposal facility in Turkey between the years 2014, 2016, and 2018 and the number of waste recycling facilities (Fig 8a). Also, a comprehensive analysis was carried out including long-term estimations of the amount of waste treated in compost and other recovery facilities versus the amount of waste treated in waste recovery facilities for the years 2014, 2016, and 2018 (Fig 8b). Zero waste practices, which are included in the circular economy approach in Turkey, mean finding solutions to waste at its source and reducing the amount of waste in production and consumption at the same time, avoiding waste and ensuring savings. The results showed that the long-term projection between the amount of waste treated in waste recovery facilities and the amount of waste processed in compost and other recovery facilities both increased linearly in the graph (Fig 8a; 8b; 9a; 9b).
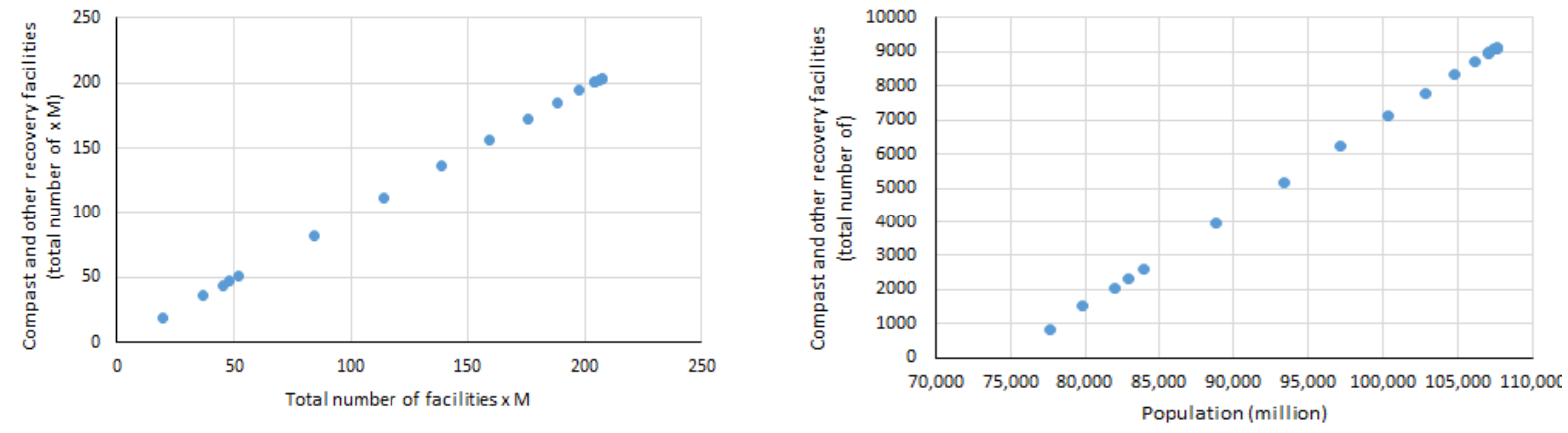

Figure 9. a) The projection between the total number of facilities (the number of waste disposal + recovery facilities) and the number of compost and other recovery facilities between 2014, 2016, and 2018 b) The projection between the population and the number of compost and other recovery facilities between 2014, 2016, and 2018

Other data relationship was made for long-term projections to make an estimation between the total number of waste disposal and recycling facilities with composting and other recycling facilities between 2014, 2016, and 2018 in Turkey (Fig 9). Also, long-term relationships between the population and the number of compost and other recovery facilities for the years 2014-2016 and 2018 were projected (Fig 9b). 


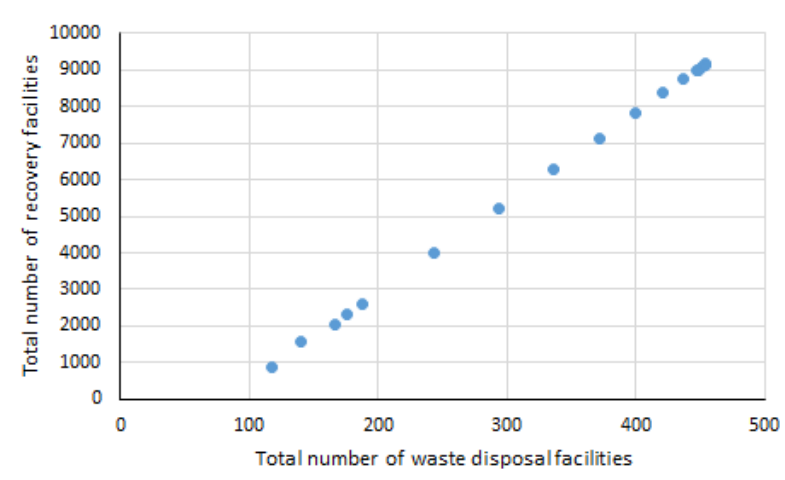

Figure 10. Projection showing the changes between the number of all waste disposal facilities and the number of all waste recovery facilities between 2014, 2016, and 2018

Another data relationship made in the present study was a projection featuring the long-term estimates of the total number of waste disposal facilities and the number of waste recovery facilities between 2014, 2016, and 2018 in Turkey (Fig 10).

\section{Results and Discussion}

As of 2016 in Turkey, 5\% of the solid wastes were recycled, 8\% were subjected to the process of composting and biomethanization, and $60 \%$ were subjected to a regular landfill. This means that, as of 2016, approximately $27 \%$ of solid wastes have been used irregularly, that is, wild storage (Turkish Environment and Urban Ministry, 2021a). Zero waste practices were initiated by the Ministry in 2017 and zero waste regulation was established in 2019. These applications aim to perform resource separation and recycling practices in the first place, and the main target is waste prevention and reduction. Furthermore, to ensure the continuity of such practices in Turkey, starting from the design and production stages, the products should be environment-friendly and the reusability of products should be ensured by using recycled materials in products. It is very important at this stage that the process of design and use of products that are recycling alternatives in product designs and both production and consumption processes is carried out with the Life Cycle Assessment (LCA) tool. LCA is a comprehensive tool to assess the environmental impacts of products, end-of-life treatments and also economies at the level of society. LCA is therefore a tool that is suitable to assess the environmental performance of circular product designs but also large-scale changes, for example the movement towards a more circular economy. The ultimate goal to lower environmental impacts is common to LCA and the CE concept (Haupt and Zschokke, 2017). LCA the environmental impact of a service, process or product from "cradle to grave". The term "cradle to cradle" defines a period from raw material production to waste disposal. Life cycle assessment is developed to evaluate different issues such as environmental impact assessment, which are not included in other environmental management methods (Özeler et al., 2006). As a result of the integration of all these applications and implementation tools, it can be argued that the process has just entered the circular economy (CE) process for Turkey in terms of solid waste management (Gökkurt Baki, 2020). All evaluations in the current study showed that, depending on the increasing of the population, 
the increase in the amount of waste continues rapidly. Accordingly, the number of facilities required for the disposal of wastes is increasing. Also, the production of waste in Turkey is high, and the increase in the level of recycling is a usual result. In this case, the separation of waste at its source, waste minimization, and the adoption of the zero-waste -currently on the agenda- approach, which is partially implemented in Turkey, as a whole country (in all production and consumption stages) will be possible. If timely action is not taken, solving the specified problems will mean serious resource losses and eventual economic losses. In the next process in Turkey, the sources should be allocated to waste separation at source and waste minimization. To successfully manage this process, efforts should be made to organize training among the employees of the relevant institutions/organizations as well as the members of the society. Public participation in the process is important and necessary for waste management to be sustainable.

\section{Conclusion}

The circular economy (CE) approach, which plays a key role in the sustainability of waste management, can be defined as an application where it is possible to reuse products and raw materials, waste is recycled to the economy, and thus energy and all resources are used efficiently and cleaner production is made in all sectors. In Turkey, if the implementation of the circular economy becomes more efficient, the expenses for local management of waste handling, collection, and disposal will be prevented. Within the context of zero waste, it has been known that waste is very common and substantial in Turkey. In this context, the reusability of food wastes, i.e., organic wastes, should be examined and evaluated as a resource suitable for reuse. Accordingly, it is a fact that carbon emission, which also includes the effects of climate change to a significant extent, will decrease.

One of the biggest obstacles to an accurate analysis of waste management in Turkey is the lack of recorded data. The efficacy of street collectors indicates unregistered data in Turkey. For such studies to be more efficient and sustainable, it is very important to establish a regular database in this context. Today, planning problems continue due to the lack of efficient and accessible data banks of relevant institutions and organizations.

\section{References}

D'Amato, A., Mancinelli, S., \& Zoli, M. (2016). Complementarity vs substitutability in waste management behaviors. Ecol. Econ., 123, 84-94.

https://doi.org/10.1016/j.ecolecon.2015.12.005

Demirer, G. N. (2003). Basic Principles of Pollution Prevention Approaches. Environment \& Engineering-Turkey Chamber of Architects and Engineers, 25, 13-20.

Ergun, O. N., Çoruh, S., \& Gökbulut, N. G. (1998). Solid waste management in the Black Sea region of Turkey. In G. Kocasoy (Ed.), The Kriton Curi International Symposium on Environmental Management in the Mediterranean Region (pp. 429-437). Vol. 1. Boğaziçi University, İstanbul, Turkey.

European Commission. (2021). [Online] Available: 
https://ec.europa.eu/eurostat/statisticsexplained/index.php?title=SDG_12_Responsible_cons umption_and_production\#cite_note-27

Feo, G., Ferrara, C., Iannone, V., \& Parente, P. (2019). Improving the efficacy of municipal solid waste collection with a communicative approach based on easily understandable indicators. Sci. Total Environ, 651, 2380-2390.

https://doi.org/10.1016/j.scitotenv.2018.10.161

General Directorate of Industry Industry and Technology. (2020). National Recycling Strategy Document and Action Plan, 2014-2017. pp. 113. [Online] Available:

http://webdosya.csb.gov.tr/db/ugds/ustmenu/...pdf

Gökkurt-Baki, O. (2020). Implemetation of the LCA Concept to the Planning of Sustainable Solid Waste Management. 5th Eurasia Waste Management Symposium, İstanbul, Turkey.

Gulec, N., Gunal, B., \& Erler, A. (2001). Assessment of soil and water contamination around an ash disposal site, Environmental Geology, 40, 331-344.

https://doi.org/10.1007/s002540000228

Haupt, M., \& Zschokke, M. (2017). How can LCA support the circular economy? -63rddiscussion forum on life cycle assessment, Zurich, Switzerland. Int J Life Cycle Assess, 22, 832-837. https://doi.org/10.1007/s11367-017-1267-1

Huang, Q., Zhao, J., Liu, M., Chen, J., Zhu, X., Wu, T., Tian, J., Wen, Y., Zhang, X., \& Wei, Y. (2018). Preparation of polyethylene polyamine@tannic acid encapsulated MgAl-layered double hydroxide for the efficient removal of copper (II) ions from aqueous solution. $J$. Taiwan Inst. Chem. Eng., 82, 92-101. https://doi.org/10.1016/j.jtice.2017.10.019

Liu, Y., Huang, H., Gan, D., Guo, L., Liu, M., Chen, J., Deng, F., Zhou, N., Zhang, X., \& Wei, Y. (2018). A facile strategy for preparation of magnetic graphene oxide composites and their potential for environmental adsorption. Ceram. Int., 44(15), 18571-18577.

https://doi.org/10.1016/j.ceramint.2018.07.081

Malinauskaite, J., Jouhara, H., Czajczynska, D., Stanchev, P, Katsou, E., Rostkowski, P., ... Spencer, N. (2017). Municipal solid waste management and waste-to-energy in the context of a circular economy and energy recycling in Europe. Energy, 141, 2013-2044. https://doi.org/10.1016/j.energy.2017.11.128

Minelgaitè, A., \& Liobikienè, G. (2019). Waste problem in European Union and its influence on waste management behaviours, Science of the Total Environment, 667, 86-93.

https://doi.org/10.1016/j.scitotenv.2019.02.313

Municipal Waste Statistics. (2016). Newsletter. [Online] Available:

http://www.tuik.gov.tr/PreHaberBultenleri.do?id=24876

Özeler, D., Yetis, U., \& Demirer, G. N. (2006). Life cycle assesment of municipal solid waste management methods: Ankara case study. Environ. Int., 32, 405-411.

https://doi.org/10.1016/j.envint.2005.10.002 


\section{Macrothink}

Environmental Management and Sustainable Development

ISSN 2164-7682

2021, Vol. 10, No. 2

Sharholy, M., Ahmad, K., Vaishya, R. C., \& Gupta, R. D. (2007). Municipal solid waste characteristics and management in Allahabad, India. Waste Management, 27, 490-496. https://doi.org/10.1016/j.wasman.2006.03.001

Stoeva, K., \& Alriksson, S. (2017). Influence of recycling programmes on waste separation behaviour. Waste Mana., 68, 732-741. https://doi.org/10.1016/j.wasman.2017.06.005

Turan, N. G., Çoruh, S., Akdemir, A., \& Ergun, O. N. (2009). Municipal solid waste management strategies in Turkey, Country Report. Waste Management, 29, 465-469. https://doi.org/10.1016/j.wasman.2008.06.004

Turan, N. G., Gökkurt-Baki. O., Ergun, O. N. (2016). Municipal Solid Waste Characteristics and Management in Sinop, Turkey. Environmental Engineering and Management Journal, 15(1), 13-18. https://doi.org/10.30638/eemj.2016.002

Turkish Court of Accounts. (2007). Waste Management in Turkey. National Regulations and Evaluation of Implementation Results, Performance Audit Report, January 2007, Editorial Team: Dr. H. Ömer Köse, Sat Ayaz, Burak Köroğlu. pp. 82.

Turkish Environment and Urban Ministry. (2021). [Online] Available:

https://cevreselgostergeler.csb.gov.tr/belediye-atiklari-miktari-ve-bertaraf-miktari-i-85749

Turkish Environment and Urban Ministry. (2021a). Ulusal Atık Yönetimi ve Eylem Planı 2023. pp. 140. [Online] Available:

http://webdosya.csb.gov.tr/db/cygm/haberler/ulusal_atık_yonet-m—eylem_plan...pdf

TurkStat. (2017). Environmental statistics. The State Institute of Statistics, Prime Ministry Republic of Turkey. [Online] Available: http://www.turkstat.gov.tr

TurkStat. (2020). Environmental Statistics, The State Institute of Statistics, Prime Ministry Republic of Turkey. [Online] Available: http://www.turkstat.gov.tr

Uslu, I. (1995). Environmental problems. Istanbul, Human Publications.

World Bank. (2013). Global Waste on Pace to Triple by 2100. [Online] Available: http://www.worldbank.org/en/news/feature/2013/10/30/global-waste-on-pace-to-triple

Yurtseven, E., Erdoğan, M. S., Erginöz, E., Vehid, S., Köksal, S., \& Kaymaz, A. (2010). Quantitative assessment of medical waste generation in the hospitals of İstanbul, Turkey. Environmental Engineering and Management Journal, 9, 833-837.

https://doi.org/10.30638/eemj.2010.111

Zeng, G., Liu, X., Liu, M., Huang, Q., Xu, D., Wan, Q., ... Wei, Y. (2016). Facile preparation of carbon nanotubes based carboxymethyl chitosan nanocomposites through combination of mussel inspired chemistry and Michael addition reaction: characterization and improved $\mathrm{Cu}$ 2+ removal capability, J. Taiwan Inst. Chem. Eng, 68, 446-454.

https://doi.org/10.1016/j.jtice.2016.09.008

Zhang, X., Huang, Q., Deng, F., Huang, H., Wan, Q., Liu. M., \& Wei, Y. (2017). Mussel-inspired fabrication of functional materials and their environmental applications: 


\section{Macrothink}

Environmental Management and Sustainable Development

ISSN 2164-7682

2021, Vol. 10, No. 2

progress and prospects. Appl. Mater., 7, 222-238. https://doi.org/10.1016/j.apmt.2017.04.001

\section{Copyright Disclaimer}

Copyright for this article is retained by the author(s), with first publication rights granted to the journal.

This is an open-access article distributed under the terms and conditions of the Creative Commons Attribution license (http://creativecommons.org/licenses/by/4.0/). 